\title{
В.С. ГЕЙНЦЕЛЬМАН И ЕГО ПРОГРАММА РЕМОНТА МАВЗОЛЕЯ ХОДЖИ АХМЕДА ЯСАВИ \\ в 1906-1908 гг.
}

\author{
() 2018 г. Ю.А. Ёлгин
}

\begin{abstract}
Обсуждение ремонта мавзолея Ходжи Ахмеда Ясави в г. Туркестане в 1906-1908 гг. - наименее известная страница в истории изучения памятника. Главенствующая роль в этой дискуссии принадлежит докладу гражданского инженера В.С. Гейнцельмана на имя Туркестанского генерал-губернатора по результатам обследования мавзолея в апреле 1906 г. Намеченные им меры по ремонту и сохранности туркестанского памятника в то время осуществить не удалось, но доклад Гейнцельмана стал программным документом, предвосхитившим почти всё, сделанное на мавзолее Ясави археологами, инженерами, архитекторами-реставраторами в XX в. Впервые в данной статье анализируются основные положения программы масштабного ремонта, изложенные В.С. Гейнцельманом в его докладе, а также в ряде других документов.

Ключевые слова: мавзолей Ходжи Ахмеда Ясави, В.С. Гейнцельман, Д.И. Субботич, Н.И. Гродеков, А.А. Бобринский, Императорская археологическая комиссия, ремонт, смета, купола, своды, конструкции
\end{abstract}

Осмотр мавзолея Ходжи Ахмеда Ясави в г. Туркестане в апреле 1906 г. - это второе значительное исследование памятника в начале XX в. после экспедиции Н.И. Веселовского, состоявшейся в 1905 г. Обследовал памятник по распоряжению Туркестанского генерал-губернатора Д.И. Субботича чиновник особых поручений по строительной части при нём В.С. Гейнцельман. Несмотря на то, что меры по изучению и сохранности мавзолея, намеченные по результатам этого обследования, были осуществлены лишь в самой малой степени, по своему научному, историческому значению и общественному резонансу, как мы полагаем, доклад В.С. Гейнцельмана о командировке в г. Туркестан превосходит работы Н.И. Веселовского.
Факты биографии. В.С. Гейнцельман был вторым [после А.Л. Бенуа - прим. авт.] архитекторомпрофессионалом дореволюционного Туркестана.

Он является автором ряда проектов известных зданий в Ташкенте и других городах Туркестанского края. Родился Вильгельм Соломонович 4 августа 1851 года в Одессе [Вавилова, 2014] [по другим данным в 1852 г. прим. авт.] [Барановский, 1893, с. 76]. В 1876 г. поступил на 4 курс Строительного училища (Института гражданских инженеров) Министерства внутренних дел в Санкт-Петербурге [Барановский, 1893, с. 76]. Выпущен в июне 1878 г. по окончании полного курса и удостоен звания Гражданского инженера с правом производить работы по строительной части, «при чём за блестящие успехи занесён на 


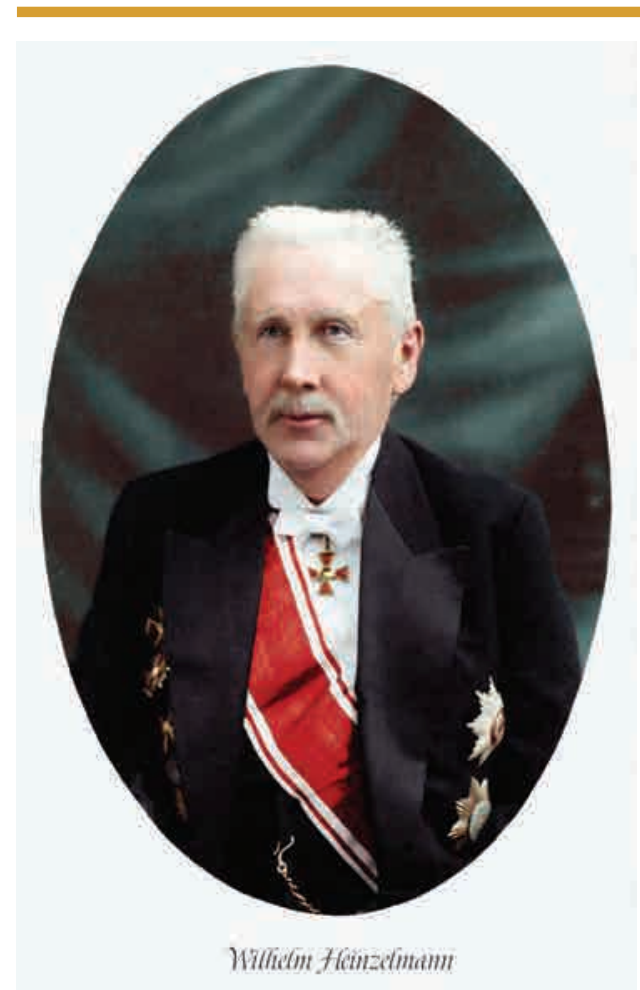

Рис.1. В.С. Гейнцельман (1851-1922) (по: [Голендер, 2007])

Fig.1. V.S. Heinzelman (1851-1922) (by: [Golender, 2007])

серебряную доску училища» [Барановский, 1893, с. 76]. Высочайшим указом от 15 сентября 1878 г. определён на службу по военно-народному управлению Туркестанского генералгубернаторства в распоряжение Туркестанского генерал-губернатора и утверждён в чине коллежского секретаря с назначением с того же числа Младшим инженером Строительного отделения Сыр-Дарьинского областного [далее СДО - прим. авт.] правления. Прибыл к месту назначения в Ташкент 2 февраля 1879 г. [Вавилова, 2014]. По Постановлению городской Думы Ташкента от 2 апреля 1884 г. избран Ташкентским городским архитектором, 24 апреля 1884 г. приказом по военно-народному ведомству зачислен в распоряжение Туркестан- ского генерал-губернатора без содержания от казны и «оставлением в должности городского архитектора» [Вавилова, 2014]. 1 января 1887 г. назначен чиновником особых поручений по строительной части при Туркестанском генерал-губернаторе [Вавилова, 2014].

В год, когда В.С. Гейнцельман приступил к работе, началось активное обсуждение ремонта мавзолея Ясави. Немного позже должно было состояться первое знакомство В.С. Гейнцельмана с этим памятником. В докладе Строительного комитета СДО правления от 2 ноября 1882 г. «О поддержании ремонтом мечети Хазрета [мавзолея Ясави прим. авт.] и минарета в г. Туркестане» говорится, что ему поручается осмотреть мавзолей и «определить, какие работы требуются» [ЦГА РУз., ф. И-17, оп. 1, д. 19184. лл. 9-9 об.]. Но он этого не смог выполнить «по болезни», а затем и вовсе «был уволен от службы» [ЦГА РУз., ф. И-17, оп. 1, д. 19184. лл. 9-9 об.].

В 1903 году в г. Туркестане сооружается новая «каменная» церковь Николая Угодника. Стройку курирует В.С. Гейнцельман, теперь уже именитый туркестанский инженер и архитектор. Неизвестно, заинтересовал ли его величественный тимуровский памятник, находящийся на обозримом расстоянии от православного храма. Скорее всего, нет. Полагаем, сказалось почти индифферентное отношение к местному архитектурному наследию, присущее инженерам и архитекторам, служившим в Туркестанском крае до революции.

Точка зрения В.С. Гейнцельмана на мавзолей Ясави изменилась в 1906 г. в результате волевого решения Туркестанского генерал-губернатора Д.И. Субботича, отправившего его в 
Ёлгин Ю.А. В.С. Гейнцельман и его программа ремонта мавзолея Ходжи Ахмеда Ясави...

г. Туркестан для обследования туркестанского памятника и изучения вопроса об его безотлагательном ремонте. На столь энергичные и скорые меры Главного начальника края подвигло одно неприятное происшествие. 11 февраля 1906 г. из усыпальницы мавзолея Ходжи Ахмеда Ясави была похищена верхняя часть одного из шести подсвечников [так долгое время в обиходе и литературе называли бронзовые светильники - сакральный дар Тимура мавзолею - прим. авт.].

Командировка в г. Туркестан. 5 апреля 1906 г. В.С. Гейнцельман получил предписание Туркестанского генерал-губернатора отправиться в г. Туркестан. 12 апреля он выехал к месту командировки и 17 апреля вернулся в Ташкент. На другой день по результатам осмотра мавзолея Ясави он сделал обстоятельный письменный доклад Туркестанскому генералгубернатору Д.И. Субботичу [далее «Доклад» - прим. авт.].

Д.И. Субботич доклад Гейнцельмана прочёл с особым вниманием. Генерал Субботич слыл человеком либеральных убеждений, за что, считается, поплатился карьерой в Туркестанском крае. За три с половиной месяца до отставки с поста Туркестанского генерал-губернатора (15.08.1906) он успел организовать официальную переписку с различными инстанциями по вопросу реализации проектов В.С. Гейнцельмана. Её продолжил сменивший Субботича генерал Н.И. Гродеков.

После ознакомления с «Докладом» Д.И. Субботич в мае 1906 г. обратился в ИАК с письмом непосредственно к её председателю графу А.А. Бобринскому с просьбой о финансовой поддержке и, выражаясь современным языком, о «научно- исторической экспертизе» проекта В.С. Гейнцельмана [ЦГА РУз., ф. Р2810, оп. 1, д. 15 , л. 10]. Инициатива туркестанских властей ИАК была воспринята весьма положительно. Но ИАК, будучи учреждением придворного типа, обладала всеми свойствами чиновной бюрократии. Через год в письме к Туркестанскому генерал-губернатору (теперь уже Н.И. Гродекову) от 22.05.1907 г. граф А.А. Бобринский сообщает, что проект Гейнцельмана находится на рассмотрении ИАК. ИАК сделала специальный запрос по этому делу архитектору А.И. Горохову, «который провёл 3 месяца в г. Туркестане в 1904 г.» [так значится в документе прим. авт.] [ЦГА РУз., ф. И-1, оп. 12, д. 828 , л. 42 об.]. В результате подобных действий В.С. Гейнцельману пришлось защищать некоторые очевидные положения «Доклада» от критики, исходящей от совершенно различных групп - от администрации в лице военных губернаторов СДО, до историков, выступавших по линии ИАК.

В конце концов, идею ремонта мавзолея Ясави в 1906-1908 гг. окончательно заболтали. 7 декабря 1908 г. В.С. Гейнцельман был уволен от службы в администрации губернаторства согласно его просьбе [Вавилова, 2014]. Генерал-губернатор Туркестана Н.И. Гродеков ещё раньше (08.03.1908) вышел в отставку по состоянию здоровья. Безотлагательный, казалось бы, ремонт мавзолея Ясави в рамках программы, разработанной В.C. Гейнцельманом, ждал своего ещё почти 20 лет. Но вопрос это в наши дни содержит важный историографический аспект, и должен быть рассмотрен с точки зрения последующих археологических и историкоархитектурных исследований. Рамки 
данной статьи не позволяют дать его анализ в полном объёме. Остановимся на ряде ключевых моментов.

О пространственных блоках. Пространственный замысел зодчих, проектировавших мавзолей Ясави, моментально захватил воображение чиновника особых поручений при Туркестанском генерал-губернаторе. «Первый взгляд на этот план, - пишет В.С. Гейнцельман, - что здание построено с громадным запасом прочности и устойчивости, рассчитанный на вечное существование [все подчёркивания в тексте доклада сделаны генерал-губернатором Субботичем - прим. авт.]. Благодаря строго обдуманному расположению масс строения, распор сводов, частью весьма значительный, преодолевается легко, можно сказать, шутя. При этом избескусны [так в документе. - прим. авт.] неуклюже толстые стены» [ЦГА РУз., ф. И-1, оп. 12, д. 828, л. 12].

В.С.Гейнцельман был в высшей степени профессионалом. Ему было достаточно взглянуть на план сооружения, чтобы представить себе в общих чертах его конструктивный замысел и объёмно-пространственную композицию. Мавзолей Ясави В.С. Гейнцельман называет «высшим проявлением зодчества». Именно это впечатление цельности, логики и гармонии пространственного замысла мавзолея в Туркестане ввело в заблуждение опытного строителя. Чёткое членение плана на восемь пространственных блоков навело B.C. Гейнцельмана на мысль о полной их самостоятельности. С этой точки зрения он смотрел на архитектуру здания в целом, представлял себе основу его конструктивной схемы, объяснял причины деформаций и появления трещин в стенах и сводах, обрушене второстепенных куполов. Однако ровно через полстолетия после доклада Гейнцельмана в ходе археологических вскрытий и архитектурных зондажей выяснилось, что самостоятельность эта весьма относительна. И она не есть панацея от разрушительных воздействий времени и природных явлений, на что немало уповал В.С. Гейнцельман.

Как и предполагал В.С. Гейнцельман, по-разному нагруженным частям мавзолея Ясави соответствовали разные фундаменты. Но конструктивная мысль на исходе царствования Тимура уже отставала от смелого пространственного замысла, воплощавшего сакральную сущность суфийского храма в Ясах: «Комбинируя в одном здании различного веса части, - пишет Л.Ю. Маньковская, - строители ещё не ставили задачу их конструктивной изоляции, хотя и опирали их на разные фундаменты» [Маньковская, 1963, с. 8].

Архитектоникапамятникатакова, что в композиционно обособленных помещениях, что ясно читается на плане, конструкции и архитектура решались в взаимозависимости помещений друг от друга и от положения данного помещения в плане. Иначе говоря, «В стенах смежных помещений шло перераспределение усилий работы арочных, сводчатых и купольных конструкций, которыми определяется тектоническая структура памятника» [Маньковская, 1962, с. 97]. Боковые помещения, особенно стены коридоров, разделяющих здание на пространственные блоки, в этом случае играют роль контрфорсов для стен казандыка, несущих громадный купол. Получается, разделённые композиционно, пространственные блоки неразрывны конструктивно (всё здание до уровня II-III этажей сложено вперевязку) [ЦГА РУз., ф. Р2810, 
Ёлгин Ю.А. В.С. Гейнцельман и его программа ремонта мавзолея Ходжи Ахмеда Ясави...

оп. 1, д. 16, лл. 6-7]. Некоторые помещения не отделены от казандыка и южного портала осадочными швами, в результате чего проседание этих, наиболее тяжёлых, частей привело к появлению широких трещин в стенах [Маньковская, 1962, с. 97-98; 1963, с. 8]. Эти трещины по-своему заменили разрезные швы.

\section{Фундаменты.}

Доклад

В.С. Гейнцельмана построен так, что почти все его положения неизменно вытекают одно из другого. Это обусловлено комплексным характером суфийского храмового сооружения, каким является мавзолей Ясави, где все составляющие объединены сакральным пространством центрального купольного зала и взаимосвязаны и конструктивно, и функционально. Поскольку разным частям здания соответствуют разные фундаменты, вопрос о грунтах и основаниях под ним также рассматривается Гейнцельманом сквозь призму идеи о самостоятельности пространственных блоков мавзолея.

Высоко оценивая архитектуру мавзолея Ясави, В.С. Гейнцельман находит в нём едва ли не единственный, но самый существенный недостаток - неудовлетворительное качество или даже отсутствие фундаментов [ЦГА РУз., ф. И-1, оп. 12, д. 828, л. 12]. Преодоление этого изъяна станет лейтмотивом инженернопрактической составляющей доклада Гейнцельмана и почти столетие будет оставаться основной проблемой ремонтно-реставрационных мероприятий по сохранению туркестанского памятника.

Обследование мавзолея Ясави в апреле 1906 г. включало одно из первых вскрытий его подземных частей («откопку фундамента», по выражению В.С. Гейнцельмана). Выявив неглубокое залегание фундаментов или их отсутствие, В.С. Гейнцельман объяснил это особенностями местной лёссовой почвы. Через полстолетия выяснилось, что, действительно, большинство стен мавзолея не имеют древних фундаментов. Основанием для них послужил слоистый лёссовый грунт, прослеживаемый на глубину 0,5-15 м, «который исследователи считают результатом заливки траншей фундаментов жидкой глиной толщиной по 1-2 см» [ЦГА РУз., оп. 1, д. 16, л. 5]. То, что В.С. Гейнцельман, а впоследствии и другие, считали фундаментами в современном понимании, было булыгой, пересыпанной трамбованной землёй, подбутовкой булыжником, смешанной с кирпично-булыжной массой, кирпичным боем под наиболее древними стенами [Маньковская, 1962, c. 98.]. На что В.С. Гейнцельман не обратил внимания - это ослабление основания стен многочисленными 2-3-ярусными погребениями вокруг мавзолея, отсутствие гидроизоляции подошвы стен и спланированного водоотвода от здания [ЦГА РУз., ф. Р2810, оп. 1, д. 16, л. 10].

В разной плотности грунтов и «невнимании» к фундаментам В.С. Гейнцельман видел одну из главных причин деформаций и разрушений. Но из контекста «Доклада» следует, что с этим он также связывает и исключительно оригинальную идею конструктивной схемы и пространственного замысла мавзолея Ясави. «Мудрый строитель, - пишет он, - несомненно, знал и предвидел это, и предпринял меры, чтобы по возможности ослабить дурные последствия неравномерной осадки. Он разъединил отдельные части шестью узкими коридорообразными помещениями [таковым также сле- 
дует считать и проходы в казандык в щипцовой стене южного портала по сторонам от парадного входа - прим. авт.], и рассчитывал на то, что каждая отдельная часть, безвредно для другой, может совершить свою осадку. Испорченные этой осадкой незначительные своды коридоров легко и недорого можно было восстановить» [ЦГА РУз., ф. И-1, оп. 12, д. 828, л. 12 об.]. Из исследования Гейнцельмана вытекает также и другая, не менее важная мысль, которую в 1950-х гг. детализировал выдающийся реставратор Б.Н. Засыпкин, что конструктивный замысел был рассчитан на дальнейшее уплотнение грунтов,, превращение их в жёсткий монолит под давлением огромной инертной массы стен и южного пештака [Ёлгин, 2013, с. 144;. ЦГА РУз., ф. Р2406, оп. 1, д. 344 , л. 7].

Выдвинув идею самостоятельности пространственных блоков, а также сделав многочисленные замеры трещин в стенах, иногда весьма значительных, В.С. Гейнцельман определил, что стены мавзолея в основном сохраняют вертикальное положение и счёл осадку «безвредной для отдельных частей строения» [ЦГА РУз., ф. И-1, оп. 12 , д. 828 , л. 12 об.].

В основном прочность здания у инженера-профессионала не вызвала тревоги. По вопросу укрепления оснований он не внёс никаких предложений. Своё мнение в отношении фундаментов под мавзолеем Ясави B.C. Гейнцельман подтвердил годом позже в письме в Канцелярию Туркестанского генерал-губернатора от 19.07.1907 г.: «Архитектор Горохов решительно восстал от подведения фундаментов под стены всей мечети. Относительно данного обстоятельства должен сказать, что по докладу моему подведение фундаментов не предположено и возражение не вполне понятно» [ЦГА РУз., ф. И-1, оп. 12, д. 828, л. 51].

Полагаем, и прагматик Гейнцельман, и менее компетентный Горохов, отдавали себе отчёт, что в первые годы XX в. кардинальное вмешательство в подземные конструкции мавзолея Ясави было нереальным по техническим и финансовым соображениям.

Пештак. В.С. Гейнцельман установил, что уклон стен казандыка внутрь достигает 5 вершков (ок. 22 см). Это, по его мнению, предусмотрено при проектировании, чтобы погасить распор гигантского купола [ЦГА РУз., ф. И-1, оп. 12, д. 828, л. 13].

Эта часть здания, как он писал в первой части доклада [генералгубернатор не преминул отчеркнуть это место вертикальной чертой на полях - прим. авт.], опасений не вызывает [ЦГА РУз., ф. И-1, оп. 12, д. 828, л. 13 об.]. Между тем с казандыком связан конструктивно гигантский южный портал (пештак), состояние которого инженер признал (несмотря на трещины) удовлетворительным наряду с куполами казандыка, гурханы и даже мечетью, давшей наибольшую осадку [ЦГА РУз., ф. И-1, оп. 12, д. 828, л. 14]. Во второй части «Доклада» В.C. Гейнцельман пишет о южном портале: «Задняя часть пештака под кровлей имеет в щипцовой стене две крупные трещины. Может быть, они произошли от давнишней осадки; но может также быть, что причина кроется в громадном своде пештака с его значительным распором. У устья портала распор этот уничтожается с громадным избытком высокими стенами с башнями» [ЦГА РУз., ф. И-1, оп. 12 , д. 828 , лл. 15-20]. 
Ёлгин Ю.А. В.С. Гейнцельман и его программа ремонта мавзолея Ходжи Ахмеда Ясави...

Южный портал мавзолея Ясави В.С. Гейнцельман характеризовал как «наиболее величественную часть всего сооружения». «Обрушение пештака, - пишет он, - было бы связано с обрушением свода над казанлыком и гибелью большей части храма» [ЦГА РУз., ф. И-1, оп. 12, д. 828, лл. 15-21]. Здесь [Гейнцельман нередко противоречит себе - прим. авт.] положение о самостоятельности пространственных блоков отходит на второй план. Словно позабыв о высказанной им же мысли о «безопасности» пештака, В.С. Гейнцельман тут же пишет: «Надо < ..> исследовать причину отклонения южной стены около башни портала [имеется в виду левый пилон пештака - прим. авт.] и предпринять соответствующие меры» [ЦГА РУз., ф. И-1, оп. 12, д. 828, л. 15 об.].

Для укрепления южного портала он предлагает установку связей, «сечение которых должно быть весьма значительное ввиду громадности расширяющейся массы». На это потребовалось бы 300 пудов железа, что очень дорого и связано с большой трудоёмкостью работ. К тому же, считает В.С. Гейнцельман, железные связи нецелесообразны, поскольку «они будут удлиняться и сокращаться, потому что не защищены от перемены температуры» [ЦГА РУз., ф. И-1, оп. 12, д. 828, л. 15]. В итоге он предлагает сделать связи деревянными. Но осуществил бы В.С. Гейнцельман эту меру, - вопрос спорный.

Мечеть. Со слабостью грунтов, их якобы продолжающимся движением и отсутствием надёжного основания В.С. Гейнцельман связывал угрожающее состояние пространственного блока (С3 угол здания мавзолея), в котором находится мечеть. В.С. Гейнцельмана волновал вопрос, продолжается ли осадка здания. Северо-западный угол сооружения, по его словам, «...не успокоился после ремонта 1885 г.» [ЦГА РУз., ф. И-1, оп. 12, д. 828, л. 13 об]. В западной [В.С. Гейнцельман ошибочно называет её южной - прим. авт.] стене фиксирует, несмотря на установленные за 20 лет до этого контрфорсы, значительное отклонение наружу, достигающее 10 вершков (ок. 45,5 см) [ЦГА РУз., ф. И-1, оп. 12 , д. 828 , л. 12 об.].

Тем не менее, несмотря на аварийное состояние мечети, работы по ней в докладе В.С. Гейнцельмана были поставлены в ряд второстепенных мер по сохранности мавзолея. В тоже время это были весьма кардинальные действия. Чтобы доходчиво объяснить суть своего предложения, В.С. Гейнцельман в тексте доклада набросал простенькую схемку, которую назвал «эскизом» и снабдил её краткими комментариями: «По наружной стороне Малой мечети возводится массивная пристройка, показанная на эскизе слабошраффированною [заштрихованной - прим. авт.]. Её надо скомпоновать в духе старой постройки и выполнить из такого же материала при высоте примерно 2/3 высоты старого здания. Предупреждая дальнейшие движения, такая пристройка может служить полезным расширением здания» [ЦГА РУз., ф. И-1, оп. 12, д. 828, л. 14 об.].

Сооружение этой «пристройки», на наш взгляд, самая неудачная мысль в докладе В.С. Гейнцельмана. Предложение инженера, вроде бы, рационально. Но вынужденность его и искусственность очевидны, так как оно идёт вразрез с архитектоникой сводчатых конструкций мечети и всего комплекса и разрушает гармони- 


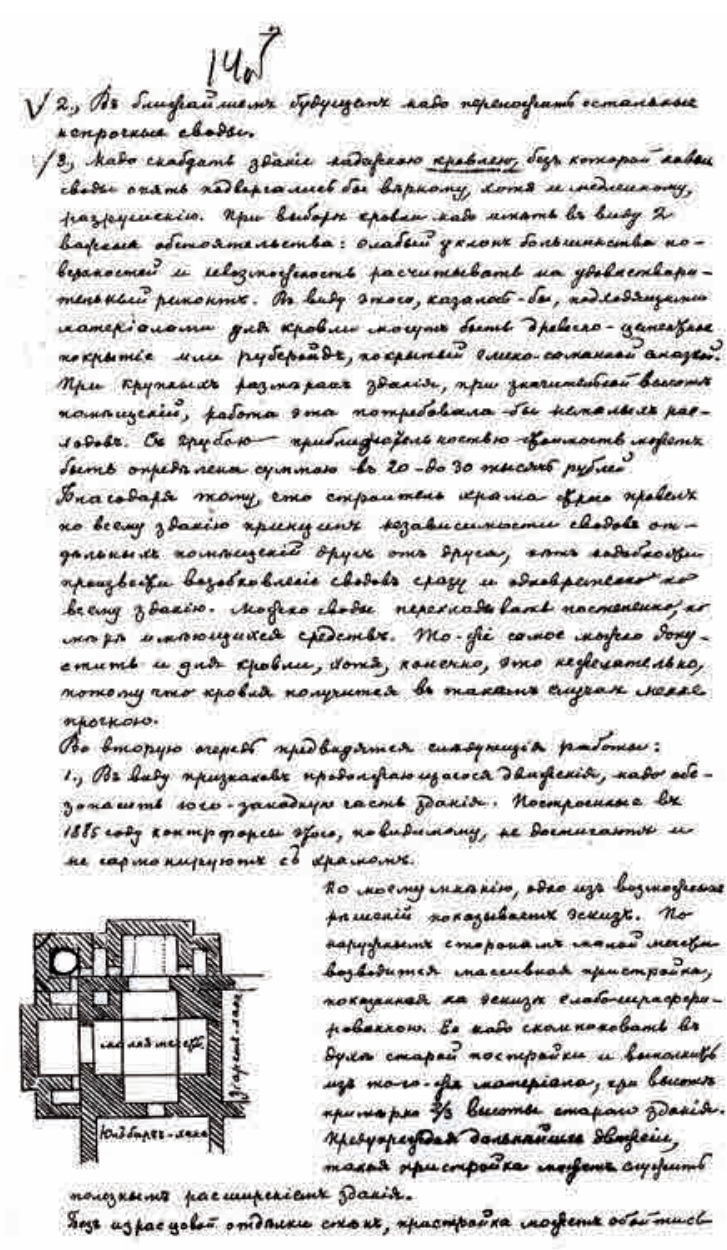

Рис. 2. Фрагмент доклада В.С. Гейниельмана Туркестанскому генерал-губернатору. 1906 г. (no: [ЦГА РУз., ф. И-1, on. 12, д. 828])

Fig. 2. The fragment of the report V.S. Heinzelman to Turkestan Governor-General. 1906 (by: [TsGA of RUz., f. I-1, op. 12, d. 828]) стенах, у инженера Гейнцельмана вызвали своды. В большинстве из них он нашёл трещины как результат неравномерной осадки разных частей здания. Эти трещины, пишет он, «...характера опасного, и даже часто угрожающего немедленным обрушением» [ЦГА РУз., ф. И-1, оп. 12, д. 828, л. 14]. Далее он приводит случай, когда мальчик-туземец, играя на крыше мавзолея, провалился через свод в «Алим-хане» [халим-хану - прим. авт.] и убился насмерть [ЦГА РУз., ф. И-1, оп. 12, д. 828 , л. 13 об.]. «За остальные своды, - пишет он дальше, - как уже было доложено, нет возможности ручаться и нет основания думать, что с ними невозможны такие же катастрофы, как со сводом Алия-хана» [это место Д.И. Субботич отчеркнул вертикальной чертой слева на полях - прим. авт.] [ЦГА РУз., ф. И-1, оп. 12, д. 828 , л. 14].

Сводам мавзолея Ясави В.С. Гейнцельман в «Докладе» уделил немало места. Большинство из них

ческий образ храма. «Полезное расширение здания» за счёт «пристройки на деле означало бы фактическую ликвидацию мечети с точки зрения функциональной и архитектурной. Один из двух проёмов, соединяющих «пристройку» с мечетью, на схеме показн на месте михраба, т.е. он подлежал уничтожению.

О сводах. Большее беспокойство, чем трещины во внешних он признал аварийными. Это притом, что все второстепенные своды, как перекладывались в течение 500 лет существования памятника [ЦГА РУз., ф. И-1, оп. 12, д. 828, л. 14]. Предвидя их неравномерную осадку, авторы планировочного и конструктивного замысла мавзолея как бы подразумевали разрушение и периодическое возобновление второстепенных свосчитает В.С. Гейнцельман, поздние, 
Ёлгин Ю.А. В.С. Гейнцельман и его программа ремонта мавзолея Ходжи Ахмеда Ясави...

дов, жертвуя их целостью для сохранности подкупольных конструкций казндыка, гурханы и мечети.

Все мероприятия по ремонту мавзолея Ясави В.С. Гейнцельман разделил на две категории: работы «неотложно необходимые» и работы второй очереди. Первым пунктом в перечне мероприятий значится «немедленная перекладка аварийных сводов» [ЦГА РУз., ф. И-1, оп. 12, д. 828, л. 14]. В письме в Канцелярию Туркестанского генерал-губернатора от 10.06.1907 г. он уточняет: «...переложить в первую нужно своды над зиарет-ханой [коридор между мечетью и гурханой - прим. авт.], над Аблай-хана, Алия-хана [коридоры - прим. авт.], над коридором у АкСарая и в самом Ак-Сарае» [думаем, имеется в виду Большой Ак-Сарай прим. авт.]. Остальные своды предполагалось переложить» в ближайшем будущем» [ЦГА РУз., ф. И-1, оп. 12, д. 828, л. 14].

О кровле. «Другой враг целостности сводов, - пишет В.С. Гейнцельман, - отсутствие надлежащей кровли». Поэтому, считает он, «... прочные своды подвергаются порче, и вообще здание [мавзолея] не защищено от разрушительного воздействия сырости и мороза» [ЦГА РУз., ф. И-1, оп. 12, д. 828, л. 14].

Устройство новой кровли наиболее рациональный и действенный момент программы ремонта мавзолея Ясави, изложенной детально и конкретно в «Докладе» и повторенной в письме его в Канцелярию Туркестанского генерал-губернатора от 10.06.1907 г. В нём изготовление кровли В.С. Гейнцельман отнёс к категории «необходимых и неотложных работ» [ЦГА РУз., ф. И-1, оп. 12, д. 828, л. 51 об.].
Если перекладку сводов В.С. Гейнцельман допускал возможным делать поэтапно, то устройство кровли должно быть, по его мнению, единовременным действием, иначе она «получится менее прочною» [ЦГА РУз., ф. И-1, оп. 12, д. 828, л. 14 об.]. Однако, как это сделать при постепенном восстановлении сводов и куполов, являющихся несущей частью для внешней оболочки кровли? В.С. Гейнцельман предложил учитывать два обстоятельства при устройстве новой кровли: слабый уклон большинства поверхностй [добавим сюда и высокий парапет по периметру крыши, задерживающий сток атмосферной влаги - прим. авт.] и «невозможность рассчитывать на удовлетворительный ремонт» [ЦГА РУз., ф. И-1, оп. 12, д. 828, л. 14]. Материалом, необходимым для новой кровли, В.С. Гейнцельман счёл «древесноцементное покрытие или рубероид, покрытый глино-саманной смазкой». Работы по устройству кровли оценивались до 30 тыс. руб. [ЦГА РУз., ф. И-1, оп. 12, д. 828, л. 14].

Конструкции надо изучать! Осознание архитектурной ценности сводов и куполов мавзолея Ясави и проблема их безотлагательного ремонта и восстановления закономерно привело В.С. Гейнцельмана к убеждению, что подкупольные конструкции памятника, их форму, архитектоническую природу и технику выполнения нужно изучать.

Даже первоочерёдные ремонты сводчатых и купольных перекрытий, утверждает В.С. Гейнцельман, должны сопровождаться исследованием их конструкции. Оно не может обойтись без изготовления подробных и точных чертежей. «Это необходимо, - пишет он, - как для поддержания здания в будущем, так и ввиду важ- 
ности его в научном отношении» [ЦГА РУз., ф. И-1, оп. 12, д. 828, л. 15 об.]. Предлагая первоочередные противоаварийные меры, В.С. Гейнцельман высказывает важную мысль, что без разборки сводов сверху, без лесов снизу невозможно определить характер их разрушений [ЦГА РУз., ф. И-1, оп. 12, д. 828, л. 14]. Сам предстоящий ремонт мавзолея Ясави B.C. Гейнцельман рассматривает как одну из возможностей архитектурноархеологического исследования памятника [ЦГА РУз., ф. И-1, оп. 12, д. 828, л. 13].

Если в «Докладе» тема изучения конструкций обозначена однимдвумя тезисами, то в 1908 г. она становится основным содержанием письма В.С. Гейнцельмана в Канцелярию Туркестанского генералгубернатора (26.01.1908). С этой проблемой им увязываются все теоретические и практические вопросы предстоящего ремонта. Он считал, что без выяснения особенностей и состояния сводчатых и подкупольных конструкций составление точной сметы ремонта невозможно [ЦГА РУз., ф. И-1, оп. 12, д. 828, л. 59]. «Как бы тщательно ни было проведено исследование сооружения, - пишет B.C. Гейнцельман, - всё же при такой археологической древности можно с уверенностью ожидать, что при [начале] производства работ окажется немало непредвиденных и потому и немалых отступлений от сметы» [ЦГА РУз., ф. И-1, оп. 12, д. 828, л. 59 об.]. Архитектурно-археологическое изучение конструкций, по мнению Гейнцельмана, сводит эти риски к минимуму. Полемизируя с неизвестным оппонентом, он пишет, что сумму в 7000 тыс. руб., запланированную для этих целей, «находит [отнюдь] не преувеличенною» [ЦГА РУз., ф. И-1, оп. 12 , д. 828 , л. 59 об.].
Полагаем, авторитет В.С. Гейнцельмана в администрации Туркестанского края был достаточно высок. Чиновник особых поручений умело доводил свои идеи и проекты до власть предержащих. В письме Исполняющего должность Туркестанского генерал-губернатора Министру Внутренних дел от 26.04.1908 г. говорится, что составление точной сметы возможно только после «обнажения и разборки» конструкций и составления чертежей, вследствие чего Военный губернатор Сыр-Дарьинской области «...признал необходимым исследовать конструкции здания, размер повреждений и составить соответственные чертежи, на что исчислил расход в 2000 руб. с лишком».

Следует заметить, что многие положения «Доклада» стали фигурировать в официальной переписке по ремонту мавзолея Ходжи Ахмеда Ясави. Чиновники всех уровней и ведомств приводили целые фрагменты почти дословно, приспосабливая их, однако, к своим ведомственным интересам. Вопрос о необходимости изучения конструкций мавзолея занимал их особенно, поскольку давал возможность тянуть с утверждением сметы на ремонт. В письме на имя Туркестанского генерал-губернатора от 09.01.1908 г. подписанном Исправляющим должность Военного губернатора Сыр-Дарьинской области и Областным инженером полковником Габбиным говорится: «Имеющиеся технические и другие документы выяснили полную невозможность составить сколько-нибудь правильно обоснованную на ремонт мечети [мавзолея Ясави - прим. авт.) смету» [ЦГА РУз., ф. И-1, оп. 12, д. 828, л. 56]. Мысль Гейнцельмана об изучении конструкций конкретизируется и переводится в практическое русло. 
Ёлгин Ю.А. В.С. Гейнцельман и его программа ремонта мавзолея Ходжи Ахмеда Ясави...

Организация архитектурных обмеров выдвигается на первый план. Полковник Габбин имеющийся на то время иконографический материал по мавзолею счёл недостаточным и намечал произвести обмер здания в целом и в деталях. В упомянутом письме он перечислил всё, необходимое для производства обмеров вплоть до верёвок и чертёжных принадлежностей [ЦГА РУз., ф. И-1, оп. 12, д. 828, л. 56]. Кое в чём он шёл дальше Гейнцельмана в своих письмах. Например, он предлагал «...собрать на месте все сведения об имеющихся по близости материалах» [по мавзолею Ясави - прим. авт.] [ЦГА РУз., ф. И-1, оп. 12, д. 828, л. 56 об.].

На обмеры мавзолея у В.С. Гейнцельмана имелся иной, чем у Н.И. Веселовского, взгляд. Он пишет: «...имеются некоторые геометрические чертежи, разъясняющие её [мечети; так до революции называли мавзолей Ходжи Ахмеда Ясави прим. авт.] размеры; но нет никаких данных о её конструкции; кроме тех, которые видны при наружном осмотре. Между тем, предположенные для восстановления проектные работы требуют сведения о конструкции здания» [ЦГА РУз., ф. И-1, оп. 12, д. 828, л. 59]. Архитектор, проектирующий здания в духе современных архитектурных стилей, В.С. Гейнцельман чисто эмпирически ищет подход к реставрации средневекового культового сооружения. «Перед разборкой каждой части [мавзолея Ясави - прим. авт.], - пишет он, - необходимо в точности изобразить графически для того, чтобы возобновление вполне согласовалось с прежним по внешнему виду» [ЦГА РУз., ф. И-1, оп. 12, д. 828 , лл. 59 об., 60].

Тут же В.С. Гейнцельман переводит изучение конструкций в сугубо практическое русло. Во время ремонта мавзолея Ясави, считает он, должен присутствовать опытный и надёжный техник с жалованьем не менее 100 руб. в месяц. Перед началом разборки конструктивных узлов должен быт инженер. Он же необходим и для «поверки сделанного техником чертежа важной формы разобранной части и для указания разборки» [ЦГА РУз., ф. И-1, оп. 12, д. 828, л. 59 об., 60]. После разборки инженер, по выражению В.С. Гейнцельмана, должен был «константировать факты» и составлять сметы или «поверять сметы, составленные техником». Он же обязан был осуществлять контроль за началом и, по мере необходимости, за ходом работ [ЦГА РУз., ф. И-1, оп. 12, д. 828, л. 60].

Приоритет изучению конструкций отдавался не только по причине их аварийного состояния, хотя предложенные им меры и очень приблизительно рассчитанная стоимость ремонтных работ планировались на обеспечение «безопасности здания», т.е. воссоздание подкупольных конструкций. Он пишет: «Для восстановления прежнего облика и блеска богатства и красоты его [мавзолея - прим. авт.] отделки потребовались бы более значительные средства, но нет практической необходимости в выполнении этой работы» [ЦГА РУз., ф. И-1, оп. 12, д. 828 , л. 15 об.].

Говоря о затратах на предстоящий ремонт, В.С. Гейнцельман счёл нужным заметить: «Эту сумму, по местным понятиям и условиям, надо, конечно, признать крупною; но по сравнению со стоимостью здания и его культурного, исторического, научного и художественного значения сумма эта кажется ничтожною. Между тем ею достигается благополучие здания на долгое время» [ЦГА РУз., ф. И-1, оп. 12, д. 828 , л. 15 об.]. 


\section{Оценивал мавзолей Ясави}

B.C. Гейнцельман исключительно как действующий памятник. Акцент в предполагаемом ремонте делается на обеспечение безопасности богослужения и на соблюдение соответствующих ритуалов поклонения могиле святого.

Вместо резюме. «Доклад» - это, по сути, одна из немногих профессионально разработанных программ по спасению конкретного памятника. Одновременно это и архитектурно-теоретическое исследование. В нём, казалось бы, инженерно-строительный аспект превалирует над историческим. Однако Гейнцельман-инженер подспудно ощущает недостаточность последнего для выбора тактики и методов масштабного ремонта, того, что можно назвать «погружением в эпоху», необходимым реставратору монументального средневекового сооружения. И Гейнцельман-архитектор через весь свой доклад, от первой страницы до последней, проводит мысль о непреходящей архитектурной, исторической и научной ценности мавзолея Ясави.

В результате трёхдневного «общения» с памятником, В.С. Гейнцельман, тогда ещё далёкий от археологии и истории архитектуры, с первого подхода выявил и разглядел очень многое, что осталось вне поля зрения художника и архитектора академической выучки, работавших в г. Туркестане три месяца незадолго до его командировки. В.С. Гейнцельман тогда не мог знать, что мавзолей Ясави не единовременная постройка, что его сооружение делится на три основных строительных периода. Но он сразу выхватил то исключительно важное, на выявление и уяснение чего после революции ушли годы и десятилетия археологических и историко-архитектурных исследований. В первые годы XX в. он высказал предположения, ставшие ключевыми вопросами в деле реставрации мавзолея через 50 лет.

\section{ЛИТЕРАТУРА}

1. Барановский В.Г. Юбилейный сборник о деятельности бывших воспитанников Института гражданских инженеров (Строительного училища). 1842-1892. СПб.: Ин-т гражданских инженеров, 1893. 406, XII с.

2. Вавилова T. В.С. Гейнцельман [Электронный ресурc] URL: https://mytashkent. uz/2014/04/03/v-s-gejntselman/

3. Голендер Б.А. Мои господа ташкентцы. История города в биографиях его знаменитых граждан. Ташкент, 2007. 264 с.

4. Ёлгин Ю.А. Археологические и историко-архитектурные исследования мавзолея Ходжи Ахмеда Ясави: вторая половина XIX в. - середина 1950-х годов: (Очерки и материалы). Алматы, 2013. 225 с.

5. Исследование, укрепление и реставрация памятника «Ахмад Ясеви» в г.Туркестане // ЦГА РУз., ф. Р2406, оп. 1, д. 344.

6. Маньковская Л.Ю. К изучению приёмов среднеазиатского зодчества конца XIV в.: (Мавзолей Ходжа Ахмеда Ясеви) // ИЗУ. 1962. Вып. І. С. 93-142.

7. Маньковская Л.Ю. Исследование архитектурного комплекса-мавзолея Ахмада Яссави в городе Туркестане и вопросы его реставрации: автореф. дис. ... канд. искусствоведения. Ташкент: изд-во АН УзССР, 1963. 18 с.

8. Маньковская Л.Ю. К истории изучения мавзолея Ходжи Ахмеда Яссави в г. Туркестане // ЦГА РУз., ф. Р2810, оп. 1, д. 15. 
Ёлгин Ю.А. В.С. Гейнцельман и его программа ремонта мавзолея Ходжи Ахмеда Ясави...

9. Маньковская Л.Ю. Ремонты и реставрация мавзолея Ахмада Яссави в городе Туркестане Казахской ССР // ЦГА РУз. Ф. Р2810, оп. 1, д. 16.

10. О неисправности мечети Хазрета Ахмета Яссави в г. Туркестане и о продаже 2-х подсвечников // ЦГА РУз. Ф. И-1, оП. 12, д. 828.

11. О разрушении памятника, выстроенного Тамерланом в 1390 г. // ЦГА РУз., ф. И-17, оп. 1, д. 19184.

\section{Сведения об авторе:}

Ёлгин Юрий Андреевич - научный сотрудник, НИИ археологических исследований, Южно-Казахстанский государственный университет им. М.О. Ауезова (г. Шымкент, Казахстан); yolginuriy@gmail.com

\section{В.С. ГЕЙНЦЕЛЬМАН ЖӘНЕ ОНЫҢ 1906-1908 ЖЖ. ҚОЖА АХМЕТ ЯССАУИ КЕСЕНЕСІН ЖӨНДЕУ БАҒДАРЛАМАСЫ}

\section{Ю.А. Ёлгин}

Түркістан қаласындағы Қожа Ахмет Яссауи кесенесін 1906-1908 жж. жөндеу жөніндегі талқылау ескерткішті зерттеу тарихының ақтаңдақ беттерінің бірі. Аталмыш пікірталаста 1906 жылдың сәуір айында ескерткішті зерттеудің қорытындылары бойынша азаматтық инженер В.С. Гейнцельманның Түркістан генерал-губернаторының атына жасаған баяндамасы басты рөл атқарады. Түркістандағы ескерткішті жөндеу және сақтау бойынша жасаған ұсыныстарын сол тұста іске асыруға мүмкіндік болмады, алайда Гейнцельманның баяндамасы XX ғасырдағы Яссауи кесенесінде жұмыс жасаған археолог, инженер, архитектор-қалпына келтірушілердің бағдарламалық құжаттары болды. Мақалада тұңғыш рет В.С. Гейнцельманның баяндамасында баяндалған ауқымды жөндеу жұмыстары және бірқатар өзге құжаттарда кездесетін негізгі қағидаттары сарапталады.

Түйін сөздер: Қожа Ахмет Яссауи кесенесі, В.С. Гейнцельман, Д.И. Субботич, Н.И. Гродеков, А.А. Бобринский, Императорлық археологиялық комиссия, жөндеу, смета, күмбез, құрылым

\section{W.S. HEINZELMANN AND HIS PROGRAM FOR REPAIR OF MAUSOLEUM OF KHOJA AHMED YASAWI IN 1906-1908}

\section{Yu.A. Yolgin}

Discussion of repair of the Mausoleum of Khoja Ahmed Yasawi in Turkestan in 1906 - 1908 years is the least studied page in the history of the monument study. The leading role in this discussion belongs to the report of W.S. Heinzelmann, civil engineer, addressed to Turkestan Governor-General on the mausoleum study results in April 1906. At that time his intended actions to repair and preserve the Turkestan monument failed, but Heinzelmann's report was a program document, anticipating almost everything done on the Yasawi mausoleum by archaeologists, engineers, architects-restorers in the XX century. For the first time this article analyzes the main provisions of the large-scale repair program stated by Heinzelmann in his report, as well as in a number of other documents.

Keywords: Mausoleum of Khoja Ahmed Yasawi, W.S. Heinzelmann, D.I. Subbotich, N.I. Grodekov, A.A. Bobrinski, Imperial archaeological committee, repair, cost account, domes, arches, constructions

\section{REFERENCES}

1. Baranovski, V. G. 1893. Yubilejnyj sbornik o deyatel'nosti byvshih vospitannikov Instituta grazhdanskih inzhenerov (Stroitel'nogo uchilishcha) (Jubilee volume about activity of former pupils of Civil engineers institute (Building academy)). Sankt-Petersburg: Institute of Civil Engineers Pub. (in Russian).

2. Vavilova, T. W.S. Heinzelmann. URL: https://mytashkent.uz/2014/04/03/v-sgejntselman//(in Russian). 
3. Golender, B. A. 2007. Moi gospoda tashkentcy. Istoriya goroda v biografiyah ego znamenityh grazhdan (My gentlemen are Tashkent. The history of the city in the biographies of its famous citizens). Tashkent (in Russian).

4. Yolgin, Yu. A. 2013. Arheologicheskie $i$ istoriko-arhitekturnye issledovaniya mavzoleya Hodzhi Ahmeda Yasavi: vtoraya polovina XIX v. - seredina 1950-h godov: (Ocherki i materialy) (Archaeological and historical-architectural studies of the Mausoleum of Khoja Ahmed Yasawi: Second half of XIX c. - middle of 1950s: (Outlines and materials)). Almaty (in Russian).

5. Central State Archive Uzbekistan, fund P2406, inv. 1, dossier 344 (in Russian).

6. Mankovskaya, L. Yu. 1963. Issledovanie arhitekturnogo kompleksa-mavzoleya Ahmada Yassavi v gorode Turkestane $i$ voprosy ego restavracii: avtoref. dis. ... kand. iskusstvovedeniya (Study of architectural complex - the Mausoleum of Ahmed Yasawi in Turkestan and issues of its restoration: thes. of Candidate of Art history). Tashkent: UzSSR Academy of Sciences (in Russian).

7. Mankovskaya, L. Yu. 1962. In Iskusstvo zodchih Uzbekistana (Art of Architects of Uzbekistan), I, 93-142 (in Russian).

8. Mankovskaya, L. Yu. In Central State Archive Uzbekistan, fund P2810, inv. 1, dossier 15 (in Russian).

9. Mankovskaya, L. Yu. In Central State Archive Uzbekistan, fund P2810, inv. 1, dossier 16 (in Russian).

10. In Central State Archive Uzbekistan, fund И-1, inv. 12, dossier 828 (in Russian). (in Russian).

11. In Central State Archive Uzbekistan, fund И-17, inv. 1, dossier 19184

\section{About the Author:}

Yolgin Yuri A. Researcher at the Institute of Archaeological Research, South Kazakhstan State University named M.O. Auezov, Shymkent, Kazakhstan; yolginuriy@gmail.com

\footnotetext{
Мүдделер қақтығысы туралы ақпаратты ашу. Автор мүдделер қақтығысының жоқтығын мәлімдейді. / Раскрытие информации о конфликте интересов. Автор заявляет об отсутствии конфликта интересов.

/ Disclosure of conflict of interest information. The author claims no conflict of interest.

Мақала туралы ақпарат / Информация о статье / Information about the article.

Редакцияға түсті / Поступила в редакцию / Entered the editorial office: 24.06.2018.

Рецензенттер мақұлдаған / Одобрено рецензентами / Approved by reviewers: 02.07.2018.

Жариялауға қабылданды / Принята к публикации / Accepted for publication: 09.07.2018.
} 